\title{
The Evaluation of Five Commercial Bacteriophage Cocktail Against Methicillin Resistant Staphylococcus Aureus Isolated From Nasal Swab Samples
}

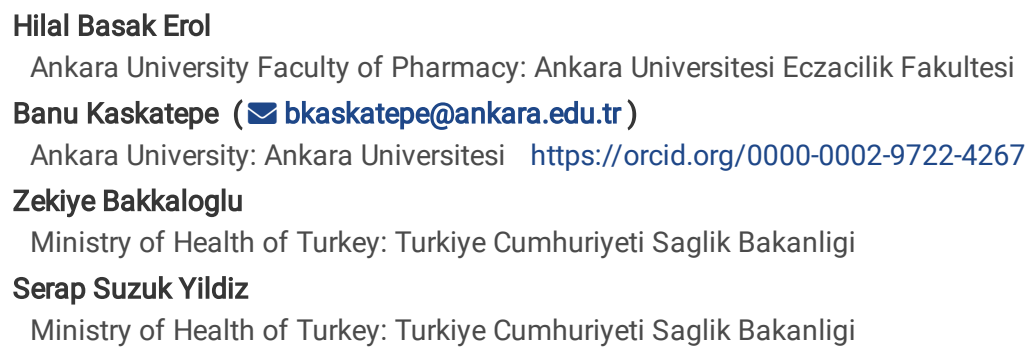

Keywords: antibiotic susceptibility, commercial phage effectivity, Methicillin resistant Staphylococcus aureus

Posted Date: July 15th, 2021

DOI: https://doi.org/10.21203/rs.3.rs-700834/v1

License: (9) (i) This work is licensed under a Creative Commons Attribution 4.0 International License. Read Full License 


\section{Abstract}

Infections due to methicillin-resistant Staphylococcus aureus (MRSA) are a growing concern for public health resulting in increase in morbidity, length of hospital stay, and cost of treatment. MRSA nasal-swab screening may give clinicians additional information for decision of empiric antimicrobial agents. While increasing antibiotic resistance leads to new treatment approaches, bacteriophages are one of the most promising methods for these alternatives. It was aimed to determine the effectiveness of bacteriophages against MRSA isolates. Nasal swab samples were collected from outpatients without any evidence of infection who applied to Hatay, Mersin and Gaziantep family and immigration health centers. A series (35) were isolate from Turkish patients, $\mathrm{G}$ series (64) were isolated from Syrian immigrants. Methicillin resistance were determined by phenotypically and genotypically. Also, antibiotic susceptibilities of all isolates were determined against erythromycin, clindamycin, gentamicin, linezolid, rifampicin, and mupirosin. The total antimicrobial resistance rates of isolates were found $11 \%, 28 \%, 8 \%, 5 \%, 16 \%, 19 \%$, and $29 \%$ respectively. The high susceptibility rate against ciprofloxacin (88.8\%) was remarkable. The overall susceptibility of MRSA strains to ENKO, INTESTI, PYO, SES, and STAPHYLOCOCCAL bacteriophages was $67.7 \%, 55.5 \%, 53.5 \%$, $61.6 \%$ and $44.4 \%$, respectively. The antibiotic susceptibility rates (except erythromycin), and efficacy of bacteriophages were higher in group A. Considering that high efficacy rates were not achieved in the study and the sensitivity rates of Turkish isolates to all phages were found higher than Syrian isolates, searching for phages in the geography where the pathogen is common, may be helpful to obtain suitable phages for treatment.

\section{Introduction}

Staphylococcus aureus (S. aureus) is the most important cause of community and hospital acquired infections all over the world and can cause different infection pictures including acute and pyogenic infections, skin and soft tissue infections, postoperative wound infections, and bacteremia. The limited treatment options due to the methicillin resistance makes the agent even more important.

Since the methicillin resistant Staphylococcus aureus (MRSA) are resistant to many antibiotics, they cause severe infections with high mortality in intensive care, surgical clinics, neonatal, hemodialysis and burn units, which require longer hospitalization and more antibiotics, and increase the rate of hospital acquired infections (Goetghebeur et al. 2007). For people who are seriously ill and need to be admitted to an intensive care unit or have had surgery, colonization with MRSA is a risk factor for a serious staphylococcal infection that can later lead to death. Over the past few decades, crucial requirements emerged to identify novel therapeutic strategies to control bacterial infections mainly due to multi-drug resistant bacteria. Bacteriophage therapy is among the prominent alternative treatment methods (Lyon 2017).

Bacteriophage therapy is a method of treating bacterial infections using unique properties of bacteriophages that only attack bacterial cells (Sulakvelidze et al. 2001). Lytic bacteriophages are similar to antibiotics in their pronounced antibacterial effects. However, bacteriophage preparations created for therapeutic purposes have some advantages and disadvantages compared to antibiotics. Bacteriophages have advantages such as protecting the natural microbiota, being non-toxic, cheap, and easily obtainable, migrating and reproducing wherever needed, regardless of the method of application, acting independently of antibiotic resistance, and being effective on biofilm, as well as some disadvantages. Hospital applications are still very limited due to the narrow spectrum of action, the fact that the agent- bacteriophage relationship has not been defined before the bacteriophage treatment and the inadequacy of clinical studies (Wittebole et al. 2014). Personalized bacteriophage therapy is seen as one of the most promising ways, especially in cases where the agent is identified and infections caused by multidrug resistant bacteria.

Bacteriophages have been used for the treatment of infectious diseases from the early 20th century, mainly in Eastern European countries whereas with the exploring of the antibiotics, lost their importance in Western countries. However, it has gained importance again with the increasing antibiotic resistance. The most essential feature, for the bacteriophage to be selected for phage therapy, is its strong lytic effect and host specificity. In some applications of bacteriophages, phages with a wide host range appear to be more useful. For this purpose, isolating and characterizing phages with a wide host range is a requirement for high therapeutic efficacy (Ross et al. 2016). Several studies have proved the efficacy of phages specific against this pathogen in different animal models and human clinical trials (Alvarez et al. 2019).

The aim of this study was to determine the efficacy of commercially available phage cocktails (PYO, INTESTI, ENKO, SES, STAPHYLOCOCCAL (STP) Bacteriophages) against $99 \mathrm{~S}$. aureus isolates characterized by phenotypic and genotypic methods.

\section{Materials And Method}

\section{Bacteriophage Cocktails}

Five commercially available bacteriophage cocktails produced by George Eliava institutions located in Tbilisi were tested. According to the manufacturers, they are all sterile-filtrate phage lysates of different bacterial species as listed below. These cocktails were purchased from the George Eliava Institute Pharmacy, Georgia. The preparation lot numbers applied during the current study are indicated. The following five commercial phage cocktails were included in this study.

\section{PYO Bacteriophage}

Pyo bacteriophage (lot \# M1-1001; Eliava BioPreparations, Tbilisi, Georgia) is a mix of sterile filtrates of phage lysates active to: Staphylococcus spp., Streptococcus spp., Different types of E. coli, Pseudomonas aeruginosa, Proteus mirabilis and Proteus vulgaris.

\section{INTESTI Bacteriophage}


Intesti bacteriophage (lot \# M2-1001; Eliava BioPreparations, Tbilisi, Georgia) is a mix of sterile filtrates of phage lysates active to: Shigella (Shigella flexneri serotype 1,2, 3, 4 and Shigella sonnei), Salmonella (S. paratyphi A, S. paratyphi B, S. typhimurium, S. enteritidis, S. choleraesuis, S. oranienburg), Different types of E. coli, Proteus mirabilis, Proteus vulgaris, Staphylococcus (S. aureus), Pseudomonas aeruginosa and Enterococcus spp.

\section{ENKO Bacteriophage}

Enko bacteriophage (lot \# E-0119; Eliava BioPreparations, Tbilisi, Georgia) active against Salmonella typhimurium, Salmonella enteritidis, Salmonella heidelberg, Salmonella newport, Salmonella cholerae, Salmonella oranienburg, Salmonella dublin and Salmonella anatum; Shigella flexneri (serovars 1, 2, $3,4)$ and Shigella sonnei (six different serovars), enteropathogenic E. coli, Staphylococcus aureus, Staphylococcus epidermidis, and Staphylococcus saprophyticus.

\section{SES Bacteriophage}

SES bacteriophage (lot \# S-0119; Eliava BioPreparations, Tbilisi, Georgia) active against Staphylococci (S. aureus, S. epidermidis and S. saprophyticus); Streptococci (Streptococcus pyogenes, Streptococcus sanguis, Streptococcus salivarius and Streptococcus agalactiae) and different serotypes of enteropathogenic $E$. coli serovars.

\section{STAPHYLOCOCCAL Bacteriophage}

Staphylococcal bacteriophage (lot \# P1-901; Eliava BioPreparations, Tbilisi, Georgia) is a mix of sterile filtrates of phage lysates active to: Staphylococcus spp.

\section{Bacterial Collection and determination of methicillin resistant}

The efficacy of commercial phage cocktails was evaluated to 99 MRSA isolates obtained from nasal swab samples. Nasal swab samples were collected from outpatients without any evidence of infection who applied to Hatay, Mersin and Gaziantep family health centers and immigration health centers. A series were isolate from Turkish patients, $\mathrm{G}$ series were isolated from Syrian immigrants.

\section{Phenotypic identification}

The nasal swab from each patient was inoculated on mannitol salt agar (HiMedia Labs, India) media and incubated aerobically overnight at $37^{\circ} \mathrm{C}$. After $24 \mathrm{~h}$ of incubation, MSA media were observed for growth. All isolates were identified by MALDI TOF MS (Bruker MALDI Biotyper, Germany) also confirmed as $S$. aureus were further tested for detection of methicillin resistance by Kirby-Bauer disc diffusion method using cefoxitin $30 \mu \mathrm{g}$ discs (HiMedia Labs, India). The standard bacterial suspension of $S$. aureus with turbidity equal to $0.5 \mathrm{McF}$ arland was inoculated on Mueller Hinton agar (HiMedia Labs, India), using the following: gentamicin $(10 \mu \mathrm{g})$, ciprofloxacin $(5 \mu \mathrm{g})$, erythromycin $(15 \mu \mathrm{g})$, clindamycin $(2 \mu \mathrm{g})$, linezolid (10 $\mu \mathrm{g})$, rifampisin $(5 \mu \mathrm{g})$, and mupirocin $(5 \mu \mathrm{g})$ (HiMedia Labs, India). The plates were incubated at $35^{\circ} \mathrm{C}$ for 24 hand the diameter of zone of growth inhibition were measured and as per European Committee on Antimicrobial Susceptibility Testing (EUCAST) guidelines (2021). The S. aureus ATCC 25923 was used for quality control strain.

\section{Molecular characterization of MRSA strains}

Molecular identification and characterization of isolated methicillin resistant $S$. aureus strains were performed by the detection of $S$. aureus-specific nuc [279 bp], MRSA-specific mecA $162 \mathrm{bp}$ ] and mecC [138 bp] genes using three different primer pairs that given in Table 1. In-house multiplex PCR was carried out on supernatants from crude DNA extracts; a bacterial suspension equal to McFarland 4 turbidity was prepared in sterile water and boiled for 10 min and subsequently centrifuged for 5 min at 10.000 g. 10 pmol of each primer was added to a DreamTaq PCR Master Mix kit (Thermo Scientific, CA, USA), and amplification was performed by using a GeneAmp PCR system 9700 thermal cycler (Applied Biosystems, CA, USA). The amplification conditions were $94^{\circ} \mathrm{C}$ for $5 \mathrm{~min}$, followed by 35 cycles at $94^{\circ} \mathrm{C}$ for $30 \mathrm{~s}, 55^{\circ} \mathrm{C}$ for $30 \mathrm{~s}$ and $72^{\circ} \mathrm{C}$ for $45 \mathrm{~s}$ with a final 7 min elongation step at $72^{\circ} \mathrm{C}$ for. Amplification products were electrophoresed through a $3 \%$ agarose gel stained with $0.5 \mathrm{~g}$ of ethidium bromide/ml. The following controls were included in all amplification reactions: NCTC 12493 (mecA-positive S. aureus), NCTC 13552 (mecC-positive S. aureus), ATCC 25923 (mecA-negative S. aureus), and negative control (water).

Table 1

Primers used for PCR reactions and expected amplicon sizes

\begin{tabular}{|c|c|c|c|}
\hline Genes & Sequences of Primers $\left(5^{\prime} \rrbracket 3^{\prime}\right)$ & Size (bp) & References \\
\hline \multirow[t]{2}{*}{$m e c-A$} & F-TCCAGATTACAACTTCACCAGG & \multirow[t]{2}{*}{162} & \multirow[t]{2}{*}{ (Oliveira and de Lencastre 2002) } \\
\hline & R-CCACTTCATATCTTGTAACG' & & \\
\hline \multirow[t]{2}{*}{$m e c-C$} & F-GAAAAAAAGGCTTAGAACGCCTC & \multirow[t]{2}{*}{138} & \multirow[t]{2}{*}{ (Stegger et al. 2012) } \\
\hline & R- GAAGATCTTTTCCGTTTTCAGC & & \\
\hline \multirow[t]{2}{*}{ nuc } & F- GCGATTGATGGTGATACGGTT & \multirow[t]{2}{*}{279} & \multirow[t]{2}{*}{ (Zhang et al. 2004) } \\
\hline & R- AGCCAAGCCTTGACGAACTAAAGC & & \\
\hline
\end{tabular}

\section{In vitro Susceptibilities of Bacteriophage Cocktails}

Spot tests were performed to determine the effectivity of five commercially available bacteriophages on 99 MRSA isolates. For spot test, all MRSA isolates were incubated at $37^{\circ} \mathrm{C}$ for $18 \mathrm{~h}$ in Mueller Hinton Agar (MHA). Single colonies were incubated in LB broth for about $3 \mathrm{~h}$. Then, bacterial culture 
(A600 ca. 0.5) inoculated on the surface of the LB agar. $10 \mu \mathrm{L}$ of phage suspension was applied on the bacterial layer after $10 \mathrm{~min}$, and incubated at $37^{\circ} \mathrm{C}$ overnight. Bacterial sensitivity to phage preparations was evaluated according to the lysis of bacteria on the agar surface. Observing of opaque, semiconfluent and confluent lysis was accepted as the isolate susceptibility. When the lysis was not observed, the corresponding isolates were determined to be resistant. The spot test was repeated three times on different days.

\section{Statistical analysis}

The data were evaluated statistically with IBM SPSS 21 packet program. Firstly, it was examined whether the data showed a normal distribution. The difference between groups $A$ and $G$ in the efficacy of each commercial preparation was determined by the Mann-Whitney $U$ test. The difference between commercial preparations was also investigated by the Kruskal Wallis test.

\section{Results}

\section{Phage and antibiotic susceptibility of bacteria}

The isolates grown in Mannitol salt agar and found to be resistant to methicillin were confirmed with molecular characterization of mec $A$, mec $C$, nuc genes. All isolates were identified as $S$. aureus with nuc gene and also all isolates were found to have the mec $A$ gene but not the mec $C$ gene. Multiplex amplification image is shown in Fig. 1. MRSA isolates were tested for antibiotic susceptibility. The total antimicrobial resistance rates of isolates were found as $11 \%, 28 \%, 8 \%, 5 \%, 16 \%, 19 \%$, and $29 \%$ for ciprofloxacin, erythromycin, clindamycin, gentamicin, linezolid, rifampicin, and mupirosin respectively. It is also considerable that intermediate sensitivity rates are high for ciprofloxacin (88\%) and mupirocin (67\%). The antibiotic susceptibility results of the isolates are given in Table 2 . 
Table 2

The results of antibiotic susceptibility and effectivity of bacteriophage

\begin{tabular}{|c|c|c|c|c|c|c|c|c|c|c|c|c|c|}
\hline \multirow[t]{2}{*}{ No } & \multirow[t]{2}{*}{ Bacterial ID } & \multicolumn{6}{|c|}{ Zone Diameter } & \multicolumn{6}{|c|}{ Bacteriophage } \\
\hline & & CIP & ERY & DA & GEN & LNZ & RFM & MPR & ENKO & INTESTI & PYO & SES & STP \\
\hline 1 & $27 A 347$ & 27 & 6 & 25 & 27 & 26 & 30 & 26 & + & - & - & + & - \\
\hline 2 & 27A 352 & 22 & 6 & 28 & 24 & 26 & 28 & 25 & ++ & ++ & ++ & + & + \\
\hline 3 & 27A 354 & 23 & 6 & 29 & 21 & 23 & 30 & 16 & - & - & - & - & - \\
\hline 4 & 27A 356 & 30 & 26 & 27 & 26 & 25 & 30 & 24 & +++ & +++ & +++ & +++ & - \\
\hline 5 & $27 A 360$ & 30 & 25 & 28 & 22 & 30 & 31 & 30 & +++ & ++ & ++ & ++ & ++ \\
\hline 6 & 27A 387 & 28 & 29 & 30 & 27 & 27 & 30 & 26 & ++ & ++ & ++ & ++ & ++ \\
\hline 7 & 27A 400 & 23 & 21 & 22 & 22 & 23 & 27 & 24 & ++ & ++ & +++ & + & + \\
\hline 8 & 27A 437 & 28 & 29 & 29 & 27 & 28 & 30 & 26 & +++ & +++ & +++ & +++ & +++ \\
\hline 9 & 27A 438 & 23 & 20 & 23 & 24 & 24 & 26 & 22 & +++ & +++ & +++ & +++ & ++ \\
\hline 10 & 27A 441 & 23 & 6 & 29 & 24 & 26 & 29 & 20 & + & - & - & - & - \\
\hline 11 & $27 A 443$ & 23 & 6 & 28 & 25 & 25 & 29 & 23 & + & - & - & + & - \\
\hline 12 & $27 A 446$ & 26 & 26 & 29 & 27 & 29 & 33 & 26 & - & - & - & - & + \\
\hline 13 & $27 A 462$ & 26 & 6 & 6 & 27 & 30 & 31 & 24 & + & - & - & ++ & - \\
\hline 14 & 27A 467 & 27 & 25 & 28 & 24 & 25 & 28 & 22 & +++ & +++ & +++ & ++ & + \\
\hline 15 & 27A 471 & 6 & 22 & 25 & 11 & 25 & 30 & 20 & ++ & +++ & +++ & +++ & +++ \\
\hline 16 & $27 A 485$ & 30 & 35 & 35 & 28 & 26 & 30 & 21 & + & + & + & + & + \\
\hline 17 & 27A 489 & 25 & 23 & 25 & 23 & 23 & 24 & 22 & ++ & ++ & +++ & ++ & + \\
\hline 18 & 27A 497 & 27 & 25 & 27 & 23 & 25 & 30 & 21 & + & + & - & + & + \\
\hline 19 & 27A 510 & 25 & 19 & 23 & 20 & 23 & 24 & 22 & +++ & +++ & +++ & + & + \\
\hline 20 & 27A 513 & 24 & 21 & 24 & 21 & 23 & 28 & 21 & + & - & - & + & - \\
\hline 21 & $27 A 523$ & 27 & 6 & 26 & 26 & 27 & 30 & 21 & - & - & - & - & - \\
\hline 22 & 27A 531 & 29 & 27 & 28 & 25 & 25 & 29 & 25 & - & +++ & +++ & - & - \\
\hline 23 & 27A 534 & 21 & 8 & 28 & 18 & 21 & 17 & 6 & + & - & - & + & - \\
\hline 24 & 27A 537 & 18 & 24 & 28 & 23 & 22 & 26 & 20 & - & - & - & - & - \\
\hline 25 & 27A 538 & 17 & 8 & 6 & 23 & 6 & 6 & 6 & - & - & - & - & - \\
\hline 26 & $27 A 80$ & 27 & 26 & 30 & 27 & 28 & 28 & 27 & ++ & ++ & ++ & + & + \\
\hline 27 & 27A 81 & 30 & 29 & 32 & 27 & 29 & 34 & 24 & +++ & +++ & +++ & +++ & +++ \\
\hline 28 & 27G 177 & 26 & 25 & 25 & 24 & 26 & 27 & 20 & +++ & +++ & +++ & ++ & ++ \\
\hline 29 & 27G 190 & 23 & 6 & 29 & 19 & 20 & 23 & 16 & + & + & + & + & + \\
\hline 30 & $27 G 200$ & 13 & 8 & 28 & 17 & 18 & 22 & 15 & ++ & - & - & ++ & - \\
\hline 31 & $27 G 217$ & 24 & 6 & 30 & 26 & 29 & 30 & 25 & - & - & - & - & - \\
\hline 32 & $27 G 241$ & 21 & 16 & 19 & 18 & 17 & 21 & 16 & - & - & - & + & - \\
\hline 33 & $27 G 266$ & 21 & 21 & 18 & 18 & 18 & 23 & 16 & - & - & - & - & - \\
\hline 34 & $27 G 270$ & 30 & 25 & 28 & 21 & 27 & 27 & 22 & + & ++ & + & + & ++ \\
\hline 35 & $27 G 280$ & 18 & 22 & 22 & 20 & 24 & 23 & 20 & + & - & - & ++ & - \\
\hline 36 & $27 G 283$ & 22 & 18 & 17 & 20 & 20 & 23 & 18 & + & +++ & +++ & + & +++ \\
\hline 37 & $27 G 284$ & 25 & 17 & 25 & 25 & 26 & 13 & 6 & + & + & + & - & - \\
\hline 38 & 27G 31 & 23 & 18 & 19 & 11 & 22 & 25 & 20 & - & - & - & - & - \\
\hline
\end{tabular}




\begin{tabular}{|c|c|c|c|c|c|c|c|c|c|c|c|c|c|}
\hline \multirow[t]{2}{*}{ No } & \multirow[t]{2}{*}{ Bacterial ID } & \multicolumn{6}{|c|}{ Zone Diameter } & \multicolumn{6}{|c|}{ Bacteriophage } \\
\hline & & CIP & ERY & DA & GEN & LNZ & RFM & MPR & ENKO & INTESTI & PYO & SES & STP \\
\hline 39 & $27 \mathrm{G} 310$ & 22 & 21 & 20 & 21 & 23 & 25 & 19 & +++ & +++ & +++ & ++ & ++ \\
\hline 40 & $27 G 338$ & 25 & 11 & 28 & 21 & 28 & 26 & 18 & ++ & ++ & +++ & ++ & ++ \\
\hline 41 & $27 \mathrm{G} 341$ & 30 & 25 & 28 & 28 & 30 & 31 & 28 & ++ & + & + & ++ & + \\
\hline 42 & $27 \mathrm{G} 343$ & 30 & 6 & 20 & 27 & 27 & 21 & 26 & ++ & + & + & ++ & + \\
\hline 43 & $27 \mathrm{G} 349$ & 22 & 21 & 22 & 21 & 22 & 24 & 18 & - & - & - & - & - \\
\hline 44 & $27 G 356$ & 25 & 22 & 27 & 21 & 23 & 25 & 17 & - & - & - & - & - \\
\hline 45 & $27 G 363$ & 23 & 20 & 19 & 19 & 17 & 25 & 16 & +++ & +++ & +++ & ++ & + \\
\hline 46 & $27 G 368$ & 21 & 20 & 22 & 21 & 21 & 25 & 17 & + & - & - & - & - \\
\hline 47 & $27 G 398$ & 23 & 19 & 19 & 18 & 18 & 20 & 17 & +++ & + & ++ & +++ & - \\
\hline 48 & $27 G 405$ & 24 & 21 & 18 & 21 & 22 & 23 & 17 & ++ & ++ & ++ & ++ & ++ \\
\hline 49 & $27 \mathrm{G} 49$ & 23 & 17 & 21 & 22 & 24 & 11 & 6 & +++ & +++ & +++ & ++ & + \\
\hline 50 & 31A 172 & 27 & 17 & 24 & 23 & 27 & 17 & 6 & - & - & - & - & - \\
\hline 51 & 31A 271 & 33 & 22 & 30 & 24 & 30 & 18 & 6 & - & - & - & - & - \\
\hline 52 & 31A 350 & 30 & 28 & 28 & 26 & 30 & 25 & 30 & - & - & - & - & - \\
\hline 53 & $31 \mathrm{~A} 55$ & 25 & 20 & 25 & 22 & 22 & 28 & 20 & - & - & - & - & - \\
\hline 54 & $31 \mathrm{G} 248$ & 25 & 25 & 26 & 24 & 28 & 30 & 26 & - & - & - & - & - \\
\hline 55 & $31 \mathrm{G} 29$ & 24 & 10 & 30 & 26 & 28 & 29 & 24 & +++ & +++ & +++ & +++ & +++ \\
\hline 56 & $31 \mathrm{G} 369$ & 27 & 25 & 28 & 17 & 30 & 30 & 27 & - & - & - & - & - \\
\hline 57 & $31 \mathrm{G} 411$ & 24 & 28 & 30 & 25 & 26 & 28 & 22 & +++ & +++ & +++ & + & + \\
\hline 58 & $31 \mathrm{G} 542$ & 25 & 25 & 29 & 26 & 27 & 30 & 23 & - & - & - & - & - \\
\hline 59 & 31G 545 & 16 & 19 & 20 & 21 & 20 & 23 & 15 & - & - & - & - & - \\
\hline 60 & $31 \mathrm{G} 549$ & 24 & 27 & 30 & 26 & 30 & 27 & 24 & + & + & + & - & - \\
\hline 61 & 31G 556 & 24 & 26 & 29 & 24 & 27 & 28 & 23 & + & - & - & + & - \\
\hline 62 & $31 \mathrm{G} 568$ & 18 & 22 & 22 & 20 & 22 & 23 & 17 & + & - & - & + & - \\
\hline 63 & 31G 577 & 26 & 24 & 26 & 20 & 26 & 26 & 24 & + & + & + & - & - \\
\hline 64 & 33A 140 & 25 & 20 & 21 & 20 & 23 & 20 & 18 & - & + & + & - & - \\
\hline 65 & 33A 212 & 21 & 20 & 22 & 21 & 21 & 25 & 17 & ++ & ++ & ++ & +++ & - \\
\hline 66 & 33A 230 & 26 & 25 & 27 & 21 & 27 & 26 & 22 & +++ & +++ & +++ & +++ & - \\
\hline 67 & 33A 248 & 27 & 23 & 27 & 22 & 27 & 28 & 23 & +++ & +++ & +++ & +++ & +++ \\
\hline 68 & 33G 136 & 24 & 20 & 22 & 21 & 20 & 25 & 17 & ++ & - & - & ++ & - \\
\hline 69 & 33G 138 & 23 & 17 & 18 & 19 & 18 & 22 & 17 & +++ & +++ & +++ & ++ & ++ \\
\hline 70 & 33G 142 & 23 & 23 & 26 & 23 & 25 & 26 & 23 & +++ & +++ & +++ & ++ & + \\
\hline 71 & 33G 147 & 25 & 6 & 26 & 19 & 24 & 30 & 20 & +++ & +++ & +++ & +++ & +++ \\
\hline 72 & 33G 15 & 6 & 6 & 32 & 33 & 32 & 31 & 27 & + & + & + & + & + \\
\hline 73 & 33G 162 & 15 & 25 & 30 & 21 & 26 & 30 & 26 & - & - & - & - & - \\
\hline 74 & 33G 170 & 21 & 22 & 24 & 22 & 21 & 25 & 20 & - & - & - & - & - \\
\hline 75 & 33G 184 & 30 & 30 & 35 & 30 & 35 & 38 & 29 & +++ & +++ & +++ & +++ & +++ \\
\hline 76 & 33G 192 & 30 & 8 & 6 & 22 & 6 & 6 & 6 & - & - & - & - & - \\
\hline 77 & 33G 199 & 20 & 19 & 23 & 20 & 19 & 19 & 18 & + & + & - & - & - \\
\hline
\end{tabular}

+++ : confluent lysis (i.e. complete lysis), ++: semiconfluent lysis (i.e. Sporadic bacteria in the lysis zone), + : opaque lysis (i.e. many bacteria in the lysis zone), -: No lysis. CIP: ciprofloxacin, ERY: erythromycin DA: clindamycin, GEN: gentamicin, LNZ: linezolid, RFM: rifampicin, MPR: mupirosin 


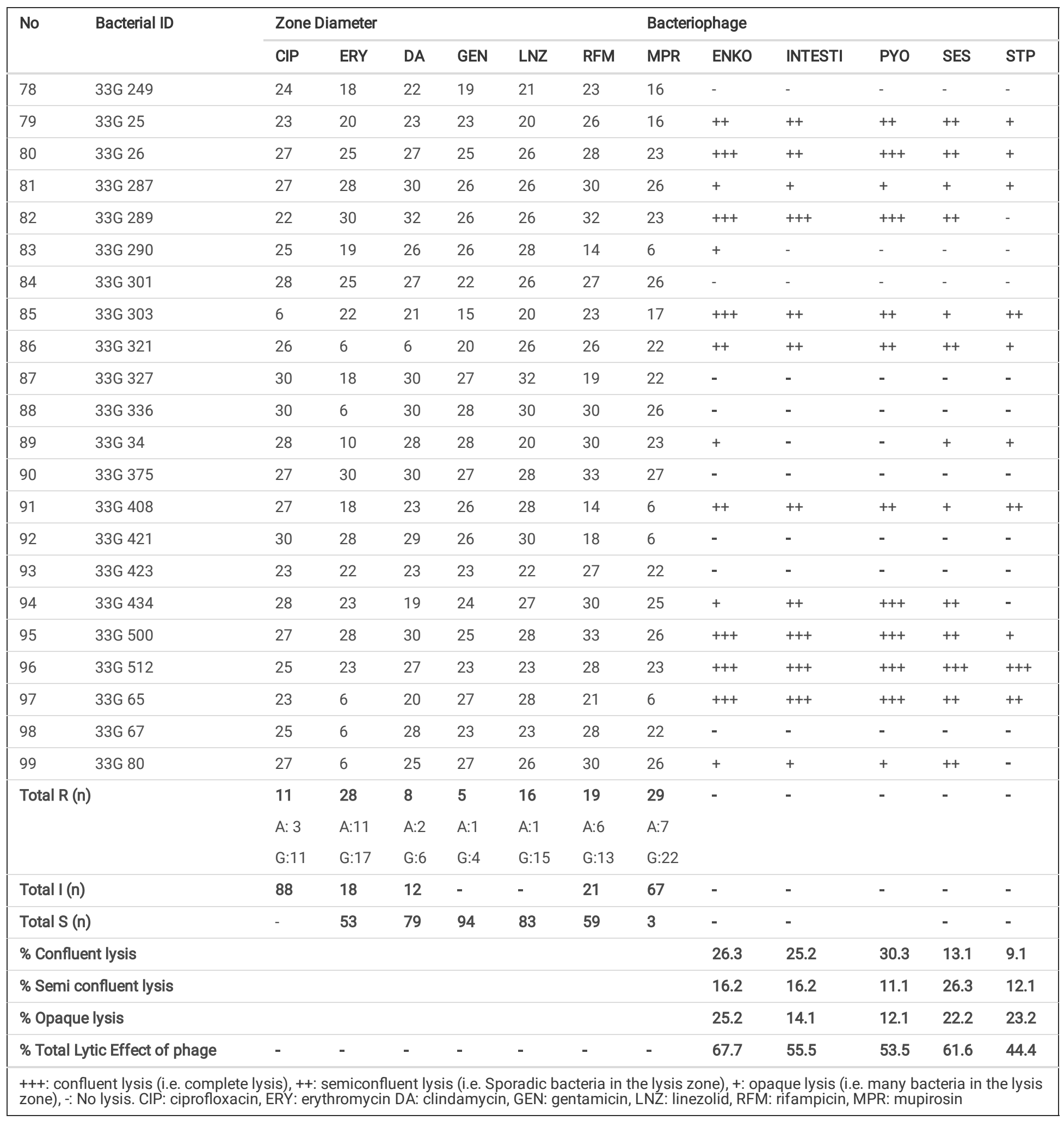

As shown in Table 2, the overall susceptibility of MRSA strains to ENKO, INTESTI, PYO, SES, and STP bacteriophages was $67.7 \%$ (including $26 / 99$ with ' +++ ' and 16/99 with ' ++ '), $55.5 \%$ (including 25/99 with ' +++ ' and 16/99 with ' ++ '), 53.5\% (including 30/99 with ' +++ ' and 11/99 with ' ++ '), $61.6 \%$ (including $13 / 99$ with '+++' and $26 / 99$ with ' ++ ') and $44.4 \%$ (including $9 / 99$ with '+++' and 12/99 with '++'), respectively.

According to the results, the most effective bacteriophage preparation was ENKO-bacteriophage (67.7\%) and the least effective one was STP bacteriophage (44.4\%). 72 (72.7\%) of 99 MRSA strains included in the study were found to be susceptible to bacteriophage cocktails. While 72 strains were found to be susceptible to at least one phage tested, $38 \mathrm{~S}$. aureus strains were found resistant to all bacteriophage tested. Although the efficacy percentages were high in group A, no statistical difference was found between the group A and G ( $p>0.05)$. There was a statistically significant difference between the activity of STP phage and the activity of Enko $(p=0.003)$, Pyo $(0.038)$ and Intesti $(p=0.050)$ phages when all commercial preparations were compared according to the lysis type. The comparison of lytic activity results in A and G groups is given in Table 3 . 
Table 3

The comparison of lytic activity results in $\mathrm{A}$ and $\mathrm{G}$ groups.

\begin{tabular}{|c|c|c|c|c|c|c|c|}
\hline & & & ENKO & INTESTI & PYO & SES & STAP \\
\hline \multirow[t]{6}{*}{99 MRSA } & A series (35) & Lytic activity (+) & 24 & 20 & 19 & 23 & 16 \\
\hline & & Lytic activity (-) & 11 & 15 & 16 & 12 & 19 \\
\hline & & \% Lytic activity & 68,6 & 57,1 & 55,3 & 65,7 & 45,7 \\
\hline & G series (64) & Lytic activity (+) & 33 & 25 & 34 & 38 & 28 \\
\hline & & Lytic activity (-) & 31 & 39 & 30 & 26 & 36 \\
\hline & & $\%$ Lytic activity & 51,6 & 39 & 53 & 59,4 & 43,8 \\
\hline
\end{tabular}

\section{Discussion}

The development of resistance to most antibiotics in many clinically important bacteria has led to increased interest in bacteriophages. They have also been used therapeutically for $\sim 100$ years, with a good safety record and there are studies in the literature showing the safety of phage applications (Abedon et al. 2017). Even though in some countries bacteriophage application has not approved yet, several examples of successful applications of personalized phage therapy have been reported (Jennes et al. 2017; Nir-Paz et al. 2019; Tkhilaishvili et al. 2020). Lytic bacteriophages that used therapy are similar to antibiotics in terms of their pronounced antibacterial effects. However, there are some advantages and disadvantages of bacteriophage preparations created for therapeutic purposes compared to antibiotics. Regardless of the way bacteriophage is applied, the factor specifically has disadvantages such as migration and reproduction there where it is needed, to act independently from antibiotic resistance, to be effective on biofilm. Hospital applications are still very limited due to the disadvantages of the narrow spectrum of action and the fact that the agent / bacteriophage relationship has not been identified before bacteriophage therapy, the potential of lysogenic bacteria to produce resistant bacteria causing changes in bacterial DNA and inadequate clinical trials. However, in today's emphasis on the need to apply personalized antibiotic therapy, personalized bacteriophage therapy is one of the most promising ways, especially in cases where the agent is identified, and when there are no other options for infections with multiple resistance microorganisms.

In our study, 99 MRSA isolates were taken from nasal swab samples of Turkish patients and Syrian immigrants. Antibiotic susceptibilities of the isolates were examined and their susceptibility to commercial phage preparations was evaluated. 35 of 99 MRSA isolates originate from Turkey patients (A group) and 64 of them originate from Syrian patients (G group). Antibiotic resistance rates of isolates in group A against CIP, ERY, DA, GEN, LNZ, RFM, MPR were detected as $8.5 \%, 31.4 \%, 5.7 \%, 2.85 \%, 2.85 \%, 17.1 \%$, and $20 \%$ respectively. In group $\mathrm{G}$ the these resistance rates were found as $12.5 \%, 26.5 \%, 9.3 \%, 6.25 \%$, $23.4 \%, 20.8 \%$, and $34 \%$. Although resistance rates were higher in the $\mathrm{G}$ group, except for erythromycin, this difference was statistically significant only for linezolid $(p=0.008)$.

Sensitivity percentages of the isolates to commercial phage preparations were found as ENKO $67.7 \%$, INTESTI $55.5 \%$, PYO 53.5\%, SES $61.6 \%$, and STP bacteriophages $44.4 \%$. Sensitivity percentages of ENKO, INTESTI, PYO, SES, STP commercial bacteriophages were found as $68.6 \%, 57.1 \%, 55.3 \%, 65.7 \%$, $45.7 \%$ for Turkish patient isolates, and $51.6 \%, 39 \%, 53 \%, 59 \%, 43.8 \%$ for Syrian immigrants respectively. Although the rates were not statistically significant between A and $\mathrm{G}$ groups, the sensitivity rates of Turkish isolates to all commercial phages were higher. Searching for phages to be used in treatment in the geography where the pathogen is common may be helpful in terms of reaching suitable phages. Commercial preparations are likely to be found more effective due to Turkey's border with Georgia and its close commercial and social relations.

In a small-scale study in Turkey by Ozkan et al.(2016) was found that PYO-bacteriophage cocktail was effective on 80\% (8/10) of $S$. aureus isolates and $90 \%(9 / 10)$ of $P$. aeruginosa isolates, FERSISI-bacteriophage cocktail was effective on $100 \%(10 / 10)$ of $P$. aeruginosa and $S$. aureus (10/10) isolates and INTESTI-bacteriophage cocktail was effective on $90 \%(9 / 10)$ of $S$. aureus isolates and $80 \%(8 / 10)$ of $P$. aeruginosa isolates. A small number of isolates taken from a single center in this study is thought to be due to high phage sensitivity. At the same time, it is highly probable that the pathogens in our study have not been encountered in Georgia before, and therefore the relevant phage is not included in the regularly updated phage cocktails. Fortunately, these resistant strains were sensitive to at least one bacteriophages. It should be noted that the majority of $S$. aureus strains included in the collection (72 of $99 ; 72.7 \%$ ) were sensitive to at least one of the tested phage products. There was no significant difference in the efficacy of lysis between antibiotic resistance. We found that phage products cause the lysis of antibiotic sensitive and resistant bacteria. This is a very important factor in deciding whether phages can be used as a clinical alternative to antibiotics. We could not find a relationship between the susceptibility of the bacterial species to the phages tested and the sensitivity to antibacterial agents.

Kuptsov et al. (2020) was found that monovalent bacteriophage products STAPHYLOCOCCAL bacteriophages demonstrated 86\% efficacy against $S$. aureus. Another study Dvorackova et al. (2019) found that the commercial polyvalent bacteriophage preparation 'Stafal phage' (Bohemia Pharmaceuticals, Czech Republic) effectively killed $83 \%$ of MRSA and $99 \%$ of MSSA (methicillin-sensitive Staphylococcus aureus). In our study, STP phage had statistically significant lower activity to MRSA isolates compared to ENKO, INTESTI, and PYO. It is thought that the use of phages as monophages is effective in seeing low efficiency. The use of phages as cocktails is thought to increase lysis efficiency.

\section{Conclusion}


As a result, infections caused by MDR pathogens pose challenges in treatment around the world. To overcome these difficulties, phage therapy as a forgotten method has regained the attention of the rest of the world except Eastern European countries. For this reason, besides in vitro phage susceptibility studies on in vivo clinical phage applications have also gained momentum. However, different activity rates of phages to different isolates due to their host specificity are one of the most important factors limiting their widespread use. It would be meaningful to expand phage libraries with effective phages to multi-drug resistant strains that cause problems in treatment, or to expand phage libraries in accordance with countries' own isolates. Well characterization of the phages obtained for this purpose and determination of their activities by in-vivo studies are also important parameters.

\section{Declarations}

- Funding

Not applicable

\section{- Conflicts of interest/Competing interests}

The authors declared that they have no conflict of interest

\section{- Ethics approval}

This study was approved by Ankara City Hospital Ethics Committee, under the approval number E19-007, 2019

- Consent to participate (include appropriate consent statements)

This manuscript is an original work and has been prepared by the authors and They aware of its content and approves its submission.

- Consent for publication (consent statement regarding publishing an individual's data or image)

The manuscript has not been published elsewhere in part or in entirety and is not under consideration by another journal. The author give their consent for publication in the Archives of Microbiology.

\section{- Availability of data and material (data transparency)}

Not applicable

\section{- Code availability (software application or custom code)}

Not applicable

\section{- Authors' contributions}

The authors have contributed to designing this study, performed research, analyzed data, and wrote the article.

\section{References}

1. Abedon ST, Garcia P, Mullany P, Aminov R (2017) Editorial: Phage Therapy: Past, Present and Future. Front Microbiol 8:981. doi:10.3389/fmicb.2017.00981

2. Alvarez A, Fernandez L, Iglesias B, Rodriguez J, Rodriguez A, Garcia P (2019) Phage therapy: unexpected drawbacks to reach hospitals. Future Virol 14(12):779-782. doi:10.2217/fvl-2019-0154

3. Dvorackova M, Ruzicka F, Benesik M, Pantucek R, Dvorakova-Heroldova M (2019) Antimicrobial effect of commercial phage preparation Stafal (R) on biofilm and planktonic forms of methicillin-resistant Staphylococcus aureus. Folia Microbiol 64(1):121-126. doi:10.1007/s12223-018-0622-3

4. EUCAST (2021) EUCAST disk diffusion method Version 9.0 January 2021. PUblisher. https://www.eucast.org/fileadmin/src/media/PDFs/EUCAST_files/Disk_test_documents/2021_manuals/Manual_v_9.0_EUCAST_Disk_Test_2021.pdf

5. Goetghebeur M, Landry PA, Han D, Vicente C (2007) Methicillin-resistant Staphylococcus aureus: A public health issue with economic consequences. Can J Infect Dis Med 18(1):27-34 doi. Doi 10.1155/2007/253947

6. Jennes S, Merabishvili M, Soentjens P, Pang KW, Rose T, Keersebilck E, Soete O, Francois PM, Teodorescu S, Verween G, Verbeken G, De Vos D, Pirnay JP (2017) Use of bacteriophages in the treatment of colistin-only-sensitive Pseudomonas aeruginosa septicaemia in a patient with acute kidney injury-a case report. Crit Care 21 doi:ARTN 129

7. 1186/s13054-017-1709-y

8. Kuptsov NS, Kornienko MA, Gorodnichev RB, Danilov DI, Malakhova MV, Parfenova N, Makarenko GI, Shitikov EA, Ilina EN (2020) Efficacy of Commercial Bacteriophage Products against Eskape Pathogens. B Russ State Med U(3):18-24 doi:10.24075/brsmu.2020.029

9. Lyon J (2017) Phage Therapy's Role in Combating Antibiotic-Resistant Pathogens. Jama-J Am Med Assoc 318(18):1746-1748. doi:10.1001/jama.2017.12938 
10. Nir-Paz R, Gelman D, Khouri A, Sisson BM, Fackler J, Alkalay-Oren S, Khalifa L, Rimon A, Yerushalmy O, Bader R, Amit S, Coppenhagen-Glazer S, Henry M, Quinones J, Malagon F, Biswas B, Moses AE, Merril G, Schooley RT, Brownstein MJ, Weil YA, Hazan R (2019) Successful Treatment of Antibioticresistant, Poly-microbial Bone Infection With Bacteriophages and Antibiotics Combination. Clin Infect Dis 69(11):2015-2018. doi:10.1093/cid/ciz222

11. Oliveira DC, de Lencastre H (2002) Multiplex PCR strategy for rapid identification of structural types and variants of the mec element in methicillinresistant Staphylococcus aureus. Antimicrob Agents Ch 46(7):2155-2161. doi:10.1128/Aac.46.7.2155-2161.2002

12. Ozkan I, Akturk E, Yeshenkulov N, Atmaca S, Rahmanov N, Atabay HI (2016) Lytic Activity of Various Phage Cocktails on Multidrug-Resistant Bacteria. Clin Invest Med 39(6):S66-S70

13. Ross A, Ward S, Hyman P (2016) More Is Better: Selecting for Broad Host Range Bacteriophages. Front Microbiol 7 doi:ARTN 1352

14. 3389/fmicb. 2016.01352

15. Stegger M, Andersen PS, Kearns A, Pichon B, Holmes MA, Edwards G, Laurent F, Teale C, Skov R, Larsen AR (2012) Rapid detection, differentiation and typing of methicillin-resistant Staphylococcus aureus harbouring either mecA or the new mecA homologue mecA(LGA251). Clin Microbiol Infec 18(4):395-400. doi:10.1111/j.1469-0691.2011.03715.x

16. Sulakvelidze A, Alavidze Z, Morris JG (2001) Bacteriophage therapy. Antimicrob Agents Ch 45(3):649-659 doi. Doi 10.1128/Aac.45.3.649-659.2001

17. Tkhilaishvili T, Winkler T, Muller M, Perka C, Trampuz A (2020) Bacteriophages as Adjuvant to Antibiotics for the Treatment of Periprosthetic Joint Infection Caused by Multidrug-Resistant Pseudomonas aeruginosa. Antimicrob Agents Ch 64(1) doi:ARTN e00924-19

18. 1128/AAC.00924 - 19

19. Wittebole X, De Roock S, Opal SM (2014) A historical overview of bacteriophage therapy as an alternative to antibiotics for the treatment of bacterial pathogens. Virulence 5(1):226-235. doi:10.4161/viru.25991

20. Zhang KY, Sparling J, Chow BL, Elsayed S, Hussain Z, Church DL, Gregson DB, Louie T, Conly JM (2004) New quadriplex PCR assay for detection of methicillin and mupirocin resistance and simultaneous discrimination of Staphylococcus aureus from coagulase-negative staphylococci. $\mathrm{J}$ Clin Microbiol 42(11):4947-4955. doi:10.1128/Jcm.42.11.4947-4955.2004

\section{Figures}

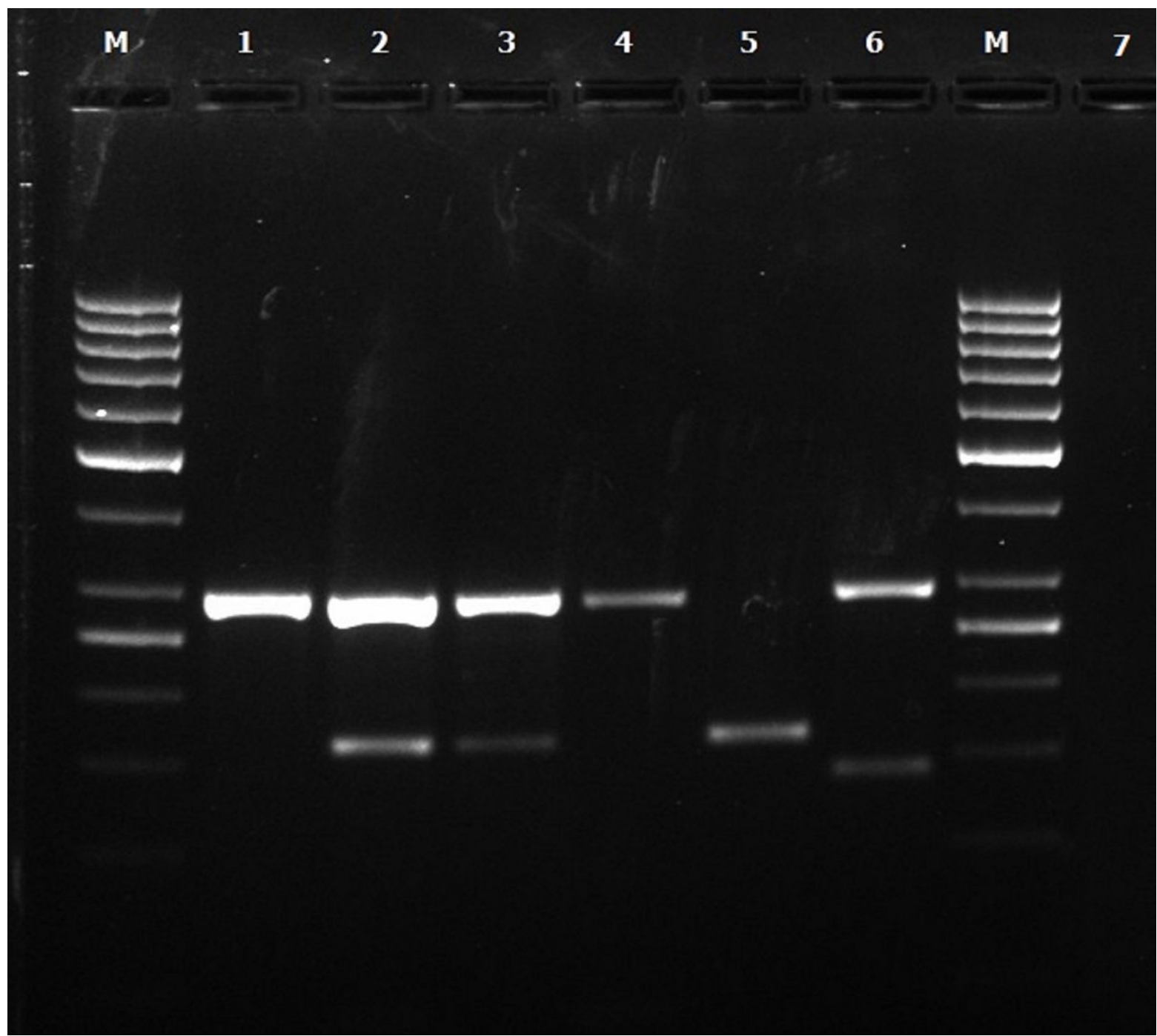




\section{Figure 1}

Multiplex amplification for the detection of S. aureus-specific (nuc), MRSA-specific (both mecA and mecC) genes. M: 50 bp size DNA Ladder (Thermo Scientific, CA, USA); Lane 1: nuc gene positive sample (35GSM25); Lane 2 and 3: nuc and mecA gene positive sample (27ASM400 and 35GSM22,

respectively); Lane 4: ATCC 25923 (mecA-negative S. aureus); Lane 5: NCTC 12493 (mecA-positive S. aureus; NCTC 13552 (mecC-positive S. aureus); Lane 7: negative control (water) 